\title{
СОСТОЯНИЕ И ТЕНДЕНЦИИ РАЗВИТИЯ РОССИЙСКОГО РЫНКА ДЕЛОВОГО ТУРИЗМА
}

\author{
Декабрьская Яна Николаевна, \\ магистрант Мининского университета \\ Крайнова Ольга Сергеевна,
} канд. экон. наук, доц., зав. кафедрой туризма филиал ЧОУВО «Московский университет им. С.Ю.Витте» в г.Нижнем Новгороде, 2. Нижний Новгород

Аннотация. Статья посвящена одному из развивающихся направлений туристских поездок - поездкам с деловой целью, оформившимся в деловой туризм. Показано, что деловой туризм играет важнейшую роль в развитии деловых, культурных и научных связей между регионами и странами и, как следствие, в развитии национальной экономики и интеграции ее в мировой рынок. В статье рассматриваются состояние и перспективы развития российского рынка делового туризма в России, учитывая региональный аспект и потенциал территорий для его развития.

Ключевые слова: бизнес-туризм, деловой туризм, российский рынок делового туризма, проблемы развития, въездной туризм.

Сегодня не вызывает сомнения тот факт, что с каждым годом деловые, культурные и научные связи между регионами и странами становятся все более интенсивными. Деловой туризм играет в этом важнейшую роль и, как следствие, развитие национальной экономики и интеграция ее в мировой рынок без развития данного направления немыслимы.

Обратившись к содержательному наполнению турпродуктов делового туризма, следует отметить, что деловая коммуникация, обмен технологиями и информацией, поиск новых рынков, поиск партнеров для инвести- 
ций и совместных проектов, продвижение компаний через PR - акции, обучение персонала и внедрение корпоративной культуры - все это деловой туризм [4].

С точки зрения потребительской ценности, в первую очередь, для бизнес-среды, деловой туризм - это один из ресурсов интеграции и развития компаний, через участие в выставках и конгрессах, через бизнесобразование, а значит и одно из важнейших условий успешного бизнеса.

В данном контексте специалисты чаще всего вместо понятия «бизнес и/ или деловой туризм» часто используют английский терминаббревиатуру - MICE, точно отражающий структуру этого вида туризма: Meetings/Incentives/Conferences/Exibitions - Деловые встречи/Инсентивтуризм/Конференции/Выставки.

Глобализация мировой экономики и связанная с этим процессом интенсификация деловых, научных и культурных связей превратили деловой туризм в одну из ведущих и наиболее динамично развивающихся отраслей мирового хозяйства, что позволило признать его экономическим феноменом XX столетия. Стоит отметить, что ежедневные расходы совершающего деловую поездку бизнесмена в среднем в три раза превышают затраты обычного туриста. И при этом, как показывают маркетинговые исследования, в отличие от других видов турпоездок в периоды любых экономических спадов и кризисов сфера делового туризма страдает менее всего, а порой даже увеличивает свои объемы.

Однако в нашей стране дело обстоит несколько иначе. Бизнестуризм, давно уже являющийся отдельным направлением в сфере услуг туроператоров, в России существует разве что в рамках индивидуального туризма. Во многом это объясняется самими субъектами туррынка тем, что деловой туризм сегодня в нашей стране не является выгодным направлением.

Тем не менее, развитие делового туризма в России - лишь вопрос времени, о чем свидетельствует, к примеру, опыт компаний, занимающих- 
ся непосредственно организацией деловых и корпоративных поездок за границу. Обращаясь в подобные организации, бизнесмен снимает с себя все хлопоты, связанные с организацией путешествия (будь-то бронирование авиабилетов, их доставка с помощью курьера заказчику, бронирование отелей, организация всех деловых поездок и, по желанию, туристических) и может сосредоточиться непосредственно на деловом процессе. Заключительным элементом в списке услуг является медицинская страховка и решение вопросов, связанных с питанием. В общем, если заказчик полностью сосредоточен на решении рабочих вопросов и ему некогда тратить время на бронирование билетов в Интернет, набирая запрос «авиабилеты стоимость», то он может приобрести услугу по организации мероприятий.

Более положительные тенденции развития имеет въездной деловой туризм. Так, в Москве, Санкт-Петербурге и областных центрах ведется строительство всевозможных бизнес-центров, гостиниц. Также наблюдается постоянный рост количества деловых форумов, конгрессов, выставок и прочих бизнес-мероприятий [3]. По статистике, более половины приезжающих иностранцев в нашу страну - бизнесмены. Соответственно, прибыльным делом сегодня считается строительство конгресс-центров и комфортабельных гостиниц, оснащенных всем необходимым для проведения деловых встреч [6].

Гораздо хуже обстоит ситуация в регионах. Туристская инфраструктура Средней полосы России практически пришла в негодность. Дальний Восток, Урал, Закавказье выживают только за счет въездного туризма, привлеченного так называемой «русской экзотикой». Стоимость транспортных услуг также не может составить конкуренцию. В сфере телекоммуникаций и связи регионы находятся далеко не в лучшем положении: если вы вдруг захотите провести бизнес-семинар в российской глубинке, соблазнившись низкими ценами на аренду и питание, то, скорее всего, можете столкнуться с такими проблемами, как отсутствие подходящего зала для 
мероприятия, наличие компьютеров, организация интернет и мобильной связи.

Тем не менее, развитие рынка бизнес-туризма в России характеризуется устойчивым ростом цен уже не первый год. По оценкам статистических агентств ежегодный рост составляет в среднем 10\%. Несмотря на неравномерное восстановление экономических отношений внутри страны, специалисты отмечают высокие шансы российского делового туризма на динамичное развитие.

Одна из причин столь позитивных ожиданий - качественные преобразования рынка на фоне ужесточающейся конкуренции. Компании предлагают корпоративным клиентам все более грамотные комплексные проекты вместо стандартного набора услуг, например: сочетание конференции и поощрительной поездки, организация сценарных развлекательных программ, расширенное участие в выставках и конференциях, сопровождающееся сопровождающей программой встреч или обучающей программой $[5]$.

В 2013 году экспертами было проведено масштабное исследование российского рынка делового туризма, итогом которого стал аналитический отчет TheBusinessTravelYearBook, содержащий детальную информацию о ситуации в отрасли и прогнозы ее развития на 2014 год. Эксперты АБТ отметили, что в 2012 году объем рынка бизнес-тревел в России составил 440 млрд рублей, а уже в 2013 году этот показатель достиг 471 млрд рублей.

Российский рынок делового туризма имеет свои характерные особенности, среди которых [1]:

- заказчики часто предпочитают совмещать в одном мероприятии деловую часть и инсентив-программу, убивая таким образом сразу двух зайцев - и поработать, и отдохнуть;

- корпоративные мероприятия наши соотечественники любят проводить на теплых курортах - в Турции, на Кипре, в Египте, Хорватии, но делать это стараются в межсезонье. В это время еще сохраняется ком- 
фортная погода, но цены на размещение и доп. услуги ниже, чем в сезон. В высокий сезон наблюдается спрос на мероприятия VIP-уровня, встречи высшего менеджмента;

- если мероприятие необходимо провести в России, то выбор заказчиков чаще всего падает на Москву и Санкт-Петербург, реже Сочи, так как в регионах сохраняются инфраструктурные проблемы, даже крупные города не всегда способны обеспечить достойный уровень сервиса и вообще принять большую группу взыскательных бизнес-туристов.

Серьезной проблемой отрасли можно считать и ее технологическую отсталость. В частности, это касается использования инструментов онлайн-бронирования авиа- и гостиничных услуг, подобных тем, которыми за рубежом много лет уверенно пользуется не только В2С, но и корпоративный сегмент. Пришло время перейти от количественного накопления информации о том, что онлайн - это полезный и эффективный инструмент, к попыткам работать с ним [5].

Российский рынок бизнес-тревел выходит из «зоны ожидания» и готовится к росту. Необходимость конкурировать в условиях глобальной экономики стимулирует компании инвестировать в деловые поездки, что делает деловой туризм приоритетным направлением деятельности для большинства компаний. Предприниматели понимают, что поездки в интересах компании - это эффективный механизм сохранения существующих и привлечения новых клиентов и партнеров, а значит, одна из наиболее перспективных долгосрочных инвестиций, важнейший катализатор роста продаж и получения прибыли.

\section{Список источников и литературы}

1. Ильина Е.Н. Туроперейтинг: организация деятельности: Учебник. - М.: Финансы и статистика, 2010. - 256 с.

2. Каурова А.Д. Организация сферы туризма: Учеб. пособие. - 2-е изд., перераб. и доп.- М.; СПб.: Изд. Дом Герда, 2011.- 319 с. 
3. Крайнова О.С., Лебедева Т.Е. Особенности государственной поддержки развития внутреннего и въездного туризма: опыт Нижегородской области. Научное обозрение. 2014. № 7-2. С.668-670.

4. Крайнова О.С., Лебедева Т.Е. Разработка и реализация целевых программ развития внутреннего и въездного туризма в Нижегородской области: потенциал для формирования конкурентоспособной туристской индустрии региона. Вестник Национальной академии туризма. 2014. №3 (31). С.37-40.

5. Крайнова, О.С. Инновационные аспекты разработки логистического подхода к управлению предприятиями индустрии туризма и гостеприимства: монография / О.С. Крайнова. Моск. ун-т им. С.Ю. Витте; ф-л Моск. ун-та им. С.Ю. Витте в г. Н. Новгород. М.: изд. «МУ им. С.Ю. Витте». 2015. $166 \mathrm{c.}$

6. Маклашина Л. Р. Деловой туризм - инструмент продвижения индустрии туризма / Л. Р. Маклашина // Актуальные вопросы экономических наук: материалы междунар. науч. конф. (г. Уфа, октябрь 2014 г.). - Уфа: Лето, 2014. — С. 122-125. 